\title{
PROTOTYPE TURBIN PELTON SEBAGAI ENERGI ALTERNATIF MIKROHIDRO DI LAMPUNG
}

\author{
Dwi Irawan \\ Jurusan Teknik Mesin Universitas Muhammadiyah Metro \\ Jl. Ki Hajar Dewantara No. 116 Kota Metro (0725) 42445-42454 \\ Email :dwi_irawan12@yahoo.co.id
}

\begin{abstract}
ABSTRAK
Energi air dapat dimanfaatkan sebagai pembangkit listrik dengan memanfaatkan tenaga potensial yang tersedia (potensi air terjun dan kecepatan aliran). Berdasarkan data Blueprint Pengelolaan Energi Nasional tahun (2005), besar potensi energi air di Indonesia adalah 75.670 MW dan yang baru dimanfaatkan 4.200 MW (5,5\%). Untuk potensi Mikrohidro adalah 458,75 MW yang baru dimanfaatkan 84 MW (18\%). Data dari Kementrian Energi dan Sumber Daya Mineral Republik Indonesia (2009), Sampai dengan akhir tahun 2008, total kapasitas terpasang pembangkit tenaga listrik nasional adalah sebesar 30.527 MW yang terdiri atas pembangkit milik PT PLN (Persero) sebesar 25.451 MW (83\%), IPP sebesar 4.159 MW (14\%) dan PPU sebesar 916 MW (3\%). Kapasitas terpasang pembangkit tersebut mengalami penambahan sebesar 25.480 MW sejak tahun 2004 atau meningkat sebesar 22\% selama periode 5 tahun. Tujuan dalam penelitian ini adalah Untuk mengatahui berapa jumlah sudu yang digunakan, Untuk mengetahui berapa daya turbin yang dihasilkan dan Untuk mengetahui efisiensi turbin pelton.

Metode yang digunakan dalam penelitian ini adalah Penelitian Lapangan (Field Research) dan Penelitian Kepustakaan (Library Research). Penelitian ini dilaksanakan di Laboratorium Universitas Muhammadiyah Metro pada bulan januari sampai april.

Hasil dalam penelitian ini terlihat bahwa daya paling tinggi pada debit $0,0005 \mathrm{~m}^{3} /$ det dengan nilai 4,97 Watt pada jumlah sudu 40. dan Efisiensi paling tinggi pada debit $0,0005 \mathrm{~m}^{3} / \mathrm{det}$ dengan nilai $49 \%$ pada jumlah sudu 40 . Jadi jumlah sudu mempengaruhi kinerja turbin Pelton terbukti bahwa jumlah sudu yang paling efektif dalam penelitian ini yaitu pada jumlah sudu 40 .
\end{abstract}

Kata Kunci : Turbin Pelton, Daya, Efisiensi.

\section{PENDAHULUAN}

Energi listrik pada saat ini merupakan energy yang sangat dibutuhkan dalam kehidupan sehari-hari baik sekala rumah tangga maupun skala industri, sehingga salah satu program pemerintah Indonesia melalui BUMN PT. PLN, dicanangkan bahwa pada tahun 2015 semua wilayah Indonesia diharapkan dapat teraliri arus listrik. Menurut Harsono di Harian Kompas, 24 Oktober 2004, besar potensi energi air di Indonesia adalah 74.976 MW, dan sebesar 70.776 MW terdapat di luar Pulau Jawa, dan yang sudah termanfaatkan adalah sebesar 3.105,76 MW. Selain PLTA, pembangkit listrik tenaga minihidro berkapasitas antara 200-5.000 kW potensinya adalah 458,75 MW, sangat layak dikembangkan untuk memenuhi kebutuhan energi listrik di daerah pedesaan yang terpencil ataupun pedesaan di pulau-pulau kecil dengan daerah aliran sungai yang sempit.

Energi potensial air dapat dimanfaatkan sebagai pembangkit listrik dengan memanfaatkan tenaga potensial yang tersedia (potensi air terjun dan kecepatan aliran). Pembangkit Listrik Tenaga Air (PLTA) adalah salah satu teknologi yang sudah terbukti tidak merusak lingkungan, menunjang diversifikasi energi sebagai pemanfaatan energi terbarukan, menunjang program pengurangan penggunaan BBM, dan sebagian besar konstruksinya menggunakan material lokal.

Penggunaan turbin air, khususnya turbin pelton banyak digunakan. Turbin jenis ini bekerja dengan memanfaatkan air jatuh / ketinggian (head). Berbagai penelitian telah dilakukan untuk mempercepat aliran dengan mengatur dimensi saluran masuk (nosel) turbin maupun bentuk sudu. 
Kinerja dari suatu turbin pelton dipengaruhi oleh ketinggian, kecepatan aliran, sudut sudu, jumlah nosel, ukuran aliran dan jumlah sudu. Jumlah sudu turbin pelton adalah salah satu variabel yang sangat mempengaruhi putaran dan gaya tangensial dalam menentukan daya dan efesiensi sebuah turbin pelton. Penambahan jumlah sudu berarti menambah jumlah gaya tangensial sehingga resultanya menjadi lebih besar, namun pertambahan jumlah sudu memungkinkan adanya pengurangan besar nilai dari masing-masing gaya tangensial tersebut secara individual tetapi resultan gayanya menjadi lebih besar, jadi dapat dikatakan bahwa dengan adanya pertambahan jumlah sudu akan menambah putaran dan gaya tangensial yang terjadi dan dengan sendirinya meningkatkan daya dan efesiensi turbin pelton, untuk itu maka penelitian ini diarahkan untuk menentukan jumlah sudu yang ideal dengan kecepatan yang divariasikan dalam menghasilkan daya turbin yang maksimal.

\section{LANDASAN TEORI}

\section{Pembangkit Listrik Tenaga Air (PLTA)}

Pembangkit Listrik Tenaga Air (PLTA) adalah suatu system pembangkit listrik yang biasanya terintegrasi dalam bendungan dengan memanfaatkan energi mekanis aliran air untuk memutar turbin yang kemudian akan diubah menjadi tenaga listrik oleh generator.

\section{Perkembangan Energi dan PLTA}

Sebagian besar negara di dunia termasuk Indonesia, suplay energi listrik masih mengandalkan bahan bakar fosil yang jumlahnya terbatas dan mulai menipis, untuk itu perlu dicarikan energi alternatif lain dan salah satunya adalah energi air. Potensi sumber energi fosil di Indonesia maupun didunia diperkirakan akan habis dalam kurun waktu tertentu akibat adanya petambahan konsumsi serta perkembangan dunia industri yang meningkat. Berdasarkan data blueprint pengelolaan energi nasional 2005-2025 yang dikeluarkan oleh Departemen Energi dan Sumber Daya Mineral (DESDM) pada tahun 2005, cadangan minyak bumi, gas dan batu bara di Indonesia akan habis dalam kurun tahun tertentu ditunjukan pada tabel 1
Tabel 1. Cadangan Energi Fosil

\begin{tabular}{|c|c|c|}
\hline Jenis Energi & \multicolumn{2}{|c|}{ Cad/Prod } \\
\cline { 2 - 3 } Fosil & Indonesia & Dunia \\
\hline Minyak & 18 Tahun & 40 Tahun \\
Gas & 61 Tahun & 60 Tahun \\
Batu Bara & 147 Tahun & 200 \\
& & Tahun \\
\hline
\end{tabular}

Sumber : DESDM (2005)

Salah satu sumber energi terbarukan yang sangat potensial di Indonesia adalah energi air dan apabila pemanfaatan energi tersebut dilakukan secara meluas diseluruh wilayah Indonesia maka peluang untuk keluar dari krisis energi akan semakin besar. Pertimbangan konversi energi dan lingkungan hidup menuntut kita untuk segera dapat memanfaatkan energi air. Berikut potensi energi terbarukan di Indonesia table 2.

Tabel 2. Potensi Energi Terbarukan di Indonesia

\begin{tabular}{|l|c|c|c|}
\hline \multicolumn{1}{|c|}{$\begin{array}{c}\text { Sumber } \\
\text { Energi }\end{array}$} & $\begin{array}{c}\text { Potensi } \\
(\mathrm{MW})\end{array}$ & $\begin{array}{c}\text { Terpasang } \\
(\mathrm{MW})\end{array}$ & $\begin{array}{c}\text { Pemanfatan } \\
(\%)\end{array}$ \\
\hline Air & 75.670 & 4.200 & 5,550 \\
Biomassa & 49.810 & 302,4 & 0,607 \\
Panas Bumi & 27.000 & 800 & 2,960 \\
Mikro Hidro & 458,75 & 84 & 18,30 \\
Energi Cahaya & 156,487 & 8 & 0,005 \\
Energi Angin & 9.286 & 0,50 & 0,005 \\
Total & 318.711, & $5.391,9$ & 27,427 \\
\multicolumn{2}{|c|}{75} & & \\
\hline
\end{tabular}

Nasional (2005 - 2025)

\section{Turbin Pelton.}

Turbin Pelton adalah turbin impuls yang dipakai untuk tinggi air jatuh yang besar. Aliran fluida kerja dalam pipa akan keluar dengan kecepatan tinggi air jatuh (h) melalui nosel. Tekanan air diubah menjadi kecepatan, pancaran air dalam akan mengenai bagian tengah - tengah sudu dan sesuai dengan perimbangan tempatnya air pancar akan belok dan ada kemungkinan membaliknya air bisa diarahkan tegak lurus. Untuk itu penampang ember dan sudu - sudunya harus ditinjau, agar mendapatkan pemindahan 
gaya yang sebaik baiknya. Turbin Pelton adalah turbin dengan kecepatan spesifik yang relatif rendah dan dengan menggunakan tinggi air jatuh yang sangat besar serta kapasitas air yang kecil dibandingkan dengan turbin jenis yang lain.

Kelebihan turbin pelton antara lain:

- Daya yang dihasilkan besal

- Kontruksi yang sederhana

- Mudah dalam perawatan

- Teknologi yang sederhana dan mudah diterapkan didaerah terisolir.

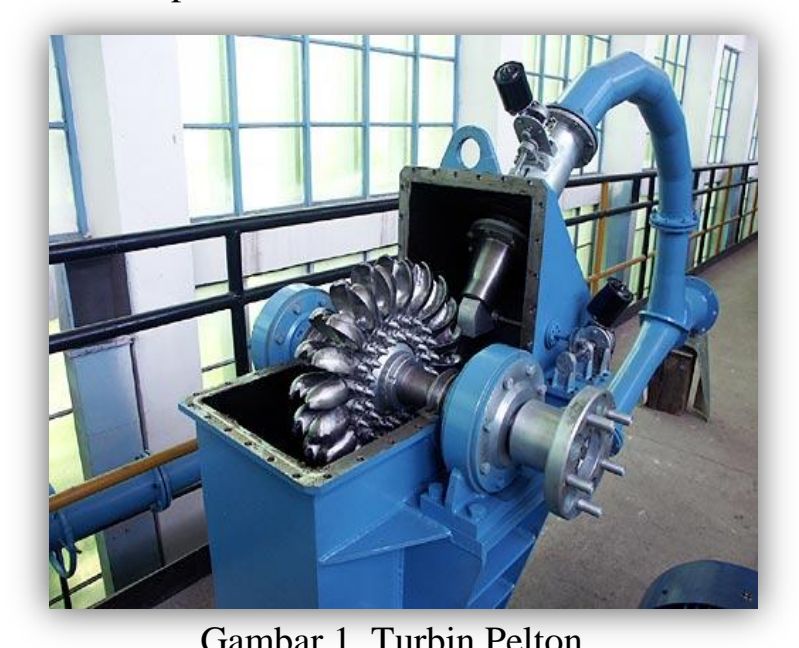

Gambar 1. Turbin Pelton

Bentuk sudu turbin terdiri dari dua bagian yang simetris. Sudu dibentuk sedemikian sehingga pancaran air akan mengenai tengahtengah sudu dan pancaran air tersebut akan berbelok ke kedua arah sehinga bisa membalikkan pancaran air dengan baik dan membebaskan sudu dari gaya-gaya samping. Untuk turbin dengan daya yang besar, sistem penyemprotan airnya dibagi lewat beberapa nozzle. Dengan demikian diameter pancaran air bisa diperkecil dan ember sudu lebih kecil.

\section{Instalasi dan Begian Utama Turbin Pelton.}

Turbin pelton biasanya berukuran besar. Hal ini dapat dimaklumi karena dioperasikan pada tekananyang tinggi danperubahan momentum yang diterima sudu-sudu sangat besar, dengan sendiri struktur turbin harus kuat. Pada turbin pelton semua energi tinggi tempet dan tekanan ketika masuk kesudu jalan turbin telah telah diubah menjadi energi kecepatan Seperti terlihat pada gambar dibawah ini:

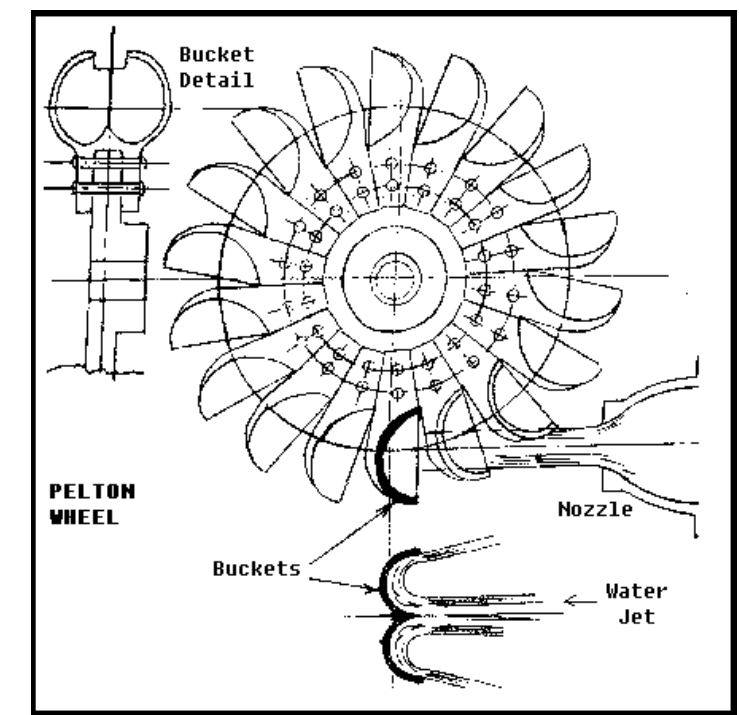

Gambar 2. Runner dan Sudu Turbin Pelton

Turbin pelton terdiri dari dua bagian utama yaitu :

- Nosel

- Runner dan Sudu

\section{NOSEL}

Nosel mempunyai beberapa fungsi yaitu:

1. Mengarahkan pancaran air ke sudu turbin.

2. Mengubah tekanan menjadi energi kinetik.

3. Mengatur kapasitas air yang masuk turbin.

Pada nosel terdapat jarum yang berfungsi untuk mengatur kapasitas dan mengkonsentrasikan air yang terpancar di mulut nosel. Panjang jarum sangat menentukan tingkat konsentrasi air, makin panjang jarum air makin terkonsentrasi.

Untuk turbin pelton dengan daya kecil, debit bisa diatur dengan hanya menggeser kedudukan jarum sudu. Untuk instalasi yang lebih besar harus menggunakan dua buah sistem pengaturan atau lebih,

Tujuan pengaturan ini adalah untuk menghindari terjadinya tekanan tumbukan yang besar dalam pipa pesat yang timbul akibat penumpukkan nosel secara tiba-tiba ketika beban turbin berkurang dengan tiba-tiba, untuk mengurangi putaran turbin pada kondisi atas, pembelokkan pancaran akan berayaun kedepan jarum nosel terlebihdahulu sehingga pancaran air dari nosel berbelok sebagian. 


\section{Runner dan Sudu}

Runner/roda jalan berfungsi sebagai roda yang memutarkan poros dari tekanan yang ditimbulkan air. Runner mempunyai jumlah sudu yang variatif terhadap diameter runner itu sendiri.

Di bagian ruuner terdapat sudu-sudu yang berfingsi sebagai penampang tekanan air dari nosel sehingga air dapat dikonsentrasikan menjadi putaran.

Runner dari sebuah turbin Pelton harus merupakan piringan melengkung yang dipasang pada poros vertikal. Pada bagian keliling luar dari runner terdapat sejumlah bucket (mangkok) secara sama baik bentuk, ukuran maupun jaraknya..

Dalam perancangan ini sudu menggunakan sendok makan yang di keeling ke runner. Runner yang dugunakan dalam perancangan ini ditentukan dengan jumlah bucket 40 buah..

\section{METODE PENELITIAN}

Dalam penelitian ini, data-data yang diperlukan dapat diperoleh melalui dua metode yaitu:

\section{Penelitian Lapangan (Field Research)}

Dengan menggunakan metode observasi yaitu dengan melakukan pengamatan secara langsung terhadap objek yang diteliti dalam hal ini limbah jamur tiram.

2. Penelitian Kepustakaan (Library Research)

Penelitian ini di maksudkan untuk mengolah data yang telah diperoleh di lapangan, memperoleh pengetahuan dan landasan teori dari beberapa literature dan hasil penelitian orang lain yang mempunyai hubungan dengan masalah yang diteliti serta dapat dipertanggungjawabkan kebenarannya.

\section{Data Lapangan}

Tabel 3. data lapangan turbin pelton

\begin{tabular}{|c|l|c|}
\hline NO. & \multicolumn{1}{|c|}{ Parameter } & Nilai \\
\hline 01 & Jumlah Sudu & 40 \\
\hline 02 & Diameter runner $(\mathrm{cm})$ & 37 \\
\hline 03 & Diameter pipa $(\mathrm{cm})$ & 1,9 \\
\hline 04 & Diameter nozzle $(\mathrm{cm})$ & 0.5 \\
\hline 05 & Debit Air divariasikan & $30,28,26$ \\
\hline
\end{tabular}

\section{Prosedur Pengujian.}

a. Studi Pustaka, studi jurnal penelitian yang relevan

b. menyiapkan alat turbin pelton

c. Mempersiapkan beberapa peralatan dan mesin yang diperlukan dalam proses pengujian.

d. Hidupkan pompa air

e. Mengukur debit air menggunakan flowmeter dengan variasi : $301 / \mathrm{m}, 28$ 1/m, 26 1/m.

f. Mengukur putaran turbin dengan menggunakan beban pada neraca pegas yang di pasang di turbin untuk menghitung gaya/ beban turbin pada putaran tertentu.

g. Pengujian
a. Mencatat data
b. Mengumpulkan data
c. Mengolah data

h. Analisis data

i. Perbaikan dan koreksi hasil penelitian

\section{HASIL DAN PERHITUNGAN \\ Data Penelitian}

Proses penelitian dengan melakukan pengujian terhadap turbin air. Pengujian ini dilakukan untuk mendapatkan data putaran (n), gaya $(\mathrm{F})$ dan perhitungan terhadap kecepatan aliran pada saluran $(\mathrm{V})$.

Data hasil pengujian turbin pelton dari masing-masing debit untuk setiap Jumlah sudu, jumlah sudu 40 , jumlah sudu 38 , jumlah sudu 36 , terdapat pada lampiran.

Tabel 4. data pengujian pengaruh beban pada jumlah sudu 40

\begin{tabular}{|c|c|c|c|c|c|}
\hline \multicolumn{2}{|c|}{ Debit Aliran } & Putaran & \multicolumn{3}{c|}{ Gaya F (N) } \\
\hline $\begin{array}{c}\text { Q } \\
(\mathbf{l} / \mathbf{m})\end{array}$ & $\begin{array}{c}\text { Q } \\
\left(\mathbf{m}^{3} / \mathbf{s}\right)\end{array}$ & $\begin{array}{c}\text { n } \\
(\text { Rpm })\end{array}$ & F1 & F2 & $\Sigma$ F \\
\hline 30 & 0.0005 & 350 & 0 & 0 & 0 \\
\hline 30 & 0.0005 & 250 & 2,6 & 0,7 & 1,9 \\
\hline 28 & 0.00046 & 298 & 0 & 0 & 0 \\
\hline 28 & 0.00046 & 225 & 2 & 0,5 & 1,5 \\
\hline 26 & 0.00043 & 246 & 0 & 0 & 0 \\
\hline 26 & 0.00043 & 190 & 1,5 & 0,4 & 1,1 \\
\hline
\end{tabular}


Tabel 5. data pengujian pengaruh beban pada jumlah sudu 38

\begin{tabular}{|c|c|c|c|c|c|}
\hline \multicolumn{2}{|c|}{ Debit Aliran } & Putaran & \multicolumn{3}{c|}{ Gaya F (N) } \\
\hline $\begin{array}{c}\text { Q } \\
(1 / \mathrm{m})\end{array}$ & $\begin{array}{c}\text { Q } \\
\left(\mathrm{m}^{3} / \mathrm{s}\right)\end{array}$ & $\begin{array}{c}\text { n } \\
(\text { Rpm })\end{array}$ & F1 & F2 & $\Sigma$ F \\
\hline 30 & 0.0005 & 304 & 0 & 0 & 0 \\
\hline 30 & 0.0005 & 243 & 2.3 & 0.6 & 1.7 \\
\hline 28 & 0.00046 & 266 & 0 & 0 & 0 \\
\hline 28 & 0.00046 & 223 & 1.9 & 0.5 & 1.4 \\
\hline 26 & 0.00043 & 228 & 0 & 0 & 0 \\
\hline 26 & 0.00043 & 180 & 1.6 & 0.3 & 1.3 \\
\hline
\end{tabular}

Tabel 6. data pengujian pengaruh beban pada jumlah sudu 36

\begin{tabular}{|c|c|c|c|c|c|}
\hline \multicolumn{2}{|c|}{ Debit Aliran } & Putaran & \multicolumn{3}{c|}{ Gaya F (N) } \\
\hline $\begin{array}{c}\text { Q } \\
(1 / \mathrm{m})\end{array}$ & $\begin{array}{c}\text { Q } \\
\left(\mathrm{m}^{3} / \mathrm{s}\right)\end{array}$ & $\begin{array}{c}\text { n } \\
(\text { Rpm })\end{array}$ & F1 & F2 & $\Sigma$ F \\
\hline 30 & 0.0005 & 280 & 0 & 0 & 0 \\
\hline 30 & 0.0005 & 233 & 2.3 & 0.7 & 1.6 \\
\hline 28 & 0.00046 & 242 & 0 & 0 & 0 \\
\hline 28 & 0.00046 & 193 & 1.9 & 0.6 & 1.3 \\
\hline 26 & 0.00043 & 204 & 0 & 0 & 0 \\
\hline 26 & 0.00043 & 153 & 1.5 & 0.4 & 1.1 \\
\hline
\end{tabular}

\section{PEMBAHASAN}

\section{Hubungan antara Debit dan Daya}

Daya sangat tergantung pada besarnya torsi dan putaran. Besaran torsi berbanding terbalik dengan putaran turbin, dimana debit air sangat berpengaruh terhadap torsi dan putaran, semakin besar debit yang diberikan akan mempengaruhi daya suatu turbin. Hubungan antara debit (Q) dan daya (P) untuk masingmasing putaran pada setiap Jumlah sudu sebagai berikut :

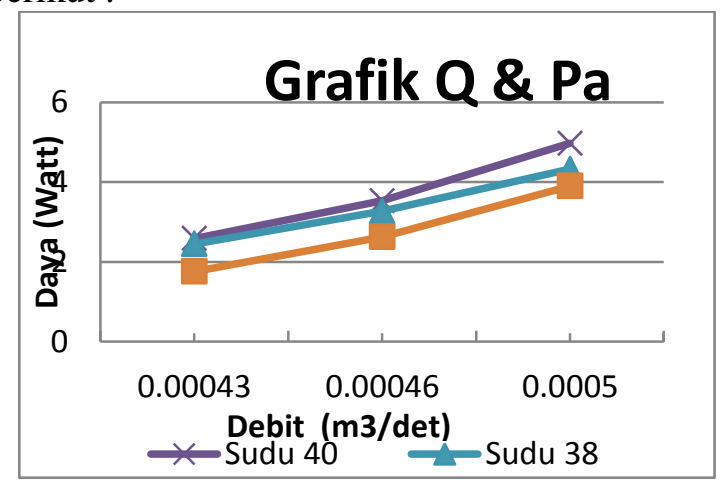

Gambar 3. Grafik Hubungan antara Debit dan Daya pada pada masing-masing jumlah sudu

Dari gambar 3. terlihat bahwa pada jumlah sudu 40 daya paling tinggi pada debit $0,0005 \mathrm{~m}^{3} /$ det dengan nilai 4,97 Watt dan yang paling rendah dengan nilai 3,9 Watt pada debit 0,00043 . Untuk jumlah sudu 38 daya paling tinggi pada debit $0,0005 \mathrm{~m}^{3} /$ det dengan nilai 3,5 Watt dan yang paling rendah dengan nilai 2,6 Watt pada debit 0,00043 . Dan pada jumlah sudu 36 daya paling tinggi pada debit $0,0005 \mathrm{~m}^{3} /$ det dengan nilai 2,58 Watt dan yang paling rendah dengan nilai 1,7 Watt pada debit 0,00043. Dari kesemuanya terlihat bahwa jumlah sudu 40 lebih baik dari jumlah sudu 38 dan 36 terlihat dari daya yang dihasilkan oleh turbin.

\section{Hubungan antara Debit dan Efisiensi}

Hubungan antara Debit dengan Efisiensi pada ketiga Jumlah sudu. pada ketiga variasi sudut sudu dapat dilihat pada gambar 4. berikut:

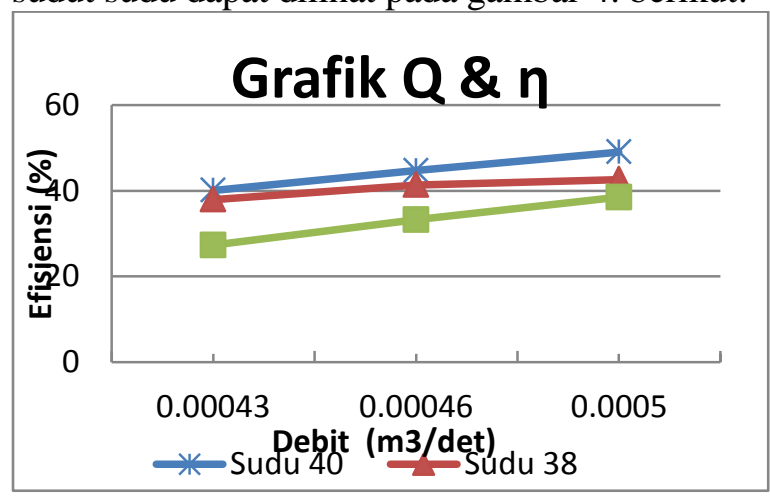

Gambar 4. Grafik Hubungan antara Debit dan Efisiensi pada pada masing-masing jumlah sudu 
Dari gambar 4. terlihat bahwa pada jumlah sudu 40 Efisiensi paling tinggi pada debit $0,0005 \mathrm{~m}^{3} /$ det dengan nilai $49 \%$ dan yang paling rendah dengan nilai $38 \%$ pada debit 0,00043 . Untuk jumlah sudu 38 Efisiensi paling tinggi pada debit $0,0005 \mathrm{~m}^{3} /$ det dengan nilai $42 \%$ dan yang paling rendah dengan nilai $37 \%$ pada debit 0,00043. Dan pada jumlah sudu 36 Efisiensi paling tinggi pada debit $0,0005 \mathrm{~m}^{3} /$ det dengan nilai $40 \%$ dan yang paling rendah dengan nilai $27 \%$ pada debit 0,00043. Dari kesemuanya terlihat bahwa jumlah sudu 40 lebih baik dari jumlah sudu 38 dan 36 terlihat dari Efisiensi yang dihasilkan oleh turbin.

\section{KESIMPULAN}

Dari hasil penelitian dan pengujian turbin pelton dapat diambil kesimpulan sebagai berikut :

1. Jadi jumlah sudu mempengaruhi kinerja turbin Pelton terbukti bahwa jumlah sudu yang paling efektif dalam penelitian ini yaitu pada jumlah sudu 40.

2. Dari ketiga Jumlah sudu daya turbin Pelton yang paling efektif yaitu pada jumlah sudu 40 pada debit $0,0005 \mathrm{~m}^{3} / \mathrm{s} 4,97$ Watt.

3. Dari ketiga jumlah sudu efisiensi turbin Pelton yang paling efektif yaitu pada jumlah sudu 40 pada debit $0.0005 \mathrm{~m}^{3} / \mathrm{s} 4,9 \%$.

\section{DAFTAR PUSTAKA}

1. Arismunandar, W., 2004. Pengerak Mula Turbin, ITB, Bandung.

2. Bono \& Indarto., 2008. Karakterisasi Daya Turbin Pelton Mikro Dengan Variasi Bentuk Sudu, Seminar Nasional Aplikasi Sains dan Teknologi, Yogyakarta

3. Blueprint. 2005. Pengelolaan energi nasional 2005 - 2025. Jakarta.

4. Dietzel, F., 1993, Turbin Pompa dan Kompresor, Erlanga, Jakarta.

5. Kadir M.Z \& Bambang,. 2010, Pengaruh tinggi sudu kincir air Terhadap daya dan efisiensi yang dihasilkan, Seminar Nasional Tahunan Teknik Mesin (SNTTM), Palembang.
6. Kementerian Energi dan Sumber Daya Mineral. 2009. Master Plan Pembangunan Ketenagalistrikan. Jakarta. Republik Indonesia

7. Pudjanarso, A. \& Nursuhud., D. 2008, Mesin Konversi Energi, Penerbit: Andi, Yogyakarta.

8. Soenoko, R., Rispinigtati, Sutikno, D. 2011. Prototype of a Twin Kinetic Turbine Performance as a Rural Electrical Power Generation, Journal of Basic and Applied Scientific Research, Universitas Brawijaya Malang.

9. Sornes K., 2010. Small-Scale Water Current Turbines For River Applications. Zero Emission Resource Organization.

10. Victor, L. Sreeter, E. Benjamin Wylie, 1988. Mekanika Fluida edisi Delapan. Andi Yogyakarta.

11. Warsito1, Sri Wahyu S., Wahyudi, D. dan Wildan Khoiron, 2011, Realisasi Dan Analisis Sumber Energi Baru Terbarukan Nanohidro Dari Aliran Air Berdebit Kecil. Jurnal Material dan Energi Indonesia, Volume 01 Nomor 01 Tahun 2011. 